Treatment.-As a rule, for ordinary cases, I gave antifebrin in $5 \mathrm{gr}$. doses; when headache was severe, antipyrin in $10 \mathrm{gr}$. doses. The latter also, in $3 \mathrm{gr}$. doses, I gave to children, partly on account of its greater solubility. For the cough that often lingered after the fever was gone, pil. ipecac. c. scilla. was used, and a tonic of quinine, nitro-muriatic acid and tinct. of perchlor. of iron was given during convalescence after severe cases. Both my native assistant and myself were attacked, and we both found antifebrin useful. In my own case, 5 grs. taken thrice brought down the temperature from over $102^{\circ}$ in the morning to $99^{\circ}$ in the evening. The following day headache was my chief symptom, and it was relieved by 10 grs. antipyrin. Some friends in Calcutta told me that they found ammoniated quinine useful in arresting threatened attacks.

A few days ago I feared we were to have a renewed outbreak of the disease, as I was called to see 4 boys in one family who had been suddenly prostrated with fever, headache, backache, and cough; but it turned out to be measles, which it must be difficult to diagnose from influenza in the case of a coloured patient, whose dusky skin often conceals a faintly developed rash.

Toondee, Manbhoom,

Bengal, 7 th .July, 1890.

\title{
THE INTERNATIONAL MEDICAL CONGRESS AT BERLIN.
}

THE Tenth International Medical Congress was held in Berlin, from the 4th to the 9th of August, 1890, and was without doubt the largest gathering of medical men that ever assembled in any city. The labour of making arrangements for such a vast assemblage was enormous, and, on the part of the comnittee, presided over by Virchow, and with Lassar as secretary, was carried through with conspicuous success. It is not our intention to attempt to give any detailed account of this great meeting, as this has already been done in a most thorough manner in the pages of the British Medical Journal and the Lancet. Our intention is rather to record the impressions of a private member, who did his best to see and to hear all that he could of what was going forward. The general impression of every member must have been that 
he formed a unit in one of the greatest medical gatherings that has ever been held, and that, while the aggregate units constituted a great and mighty organism, the individual elements of it, however distinguished in their special spheres, were, in the presence of this vast representation of universal medical science and art, but humble and even insignificant parts of a magnificent whole. The effect of such a gathering on all thoughtful minds was in the highest degree stimulating, enforcing the truth that it is the duty of every man to do what his hand finds to do with all his might.

We arrived in Berlin in the early morning hours of Saturday, the 2nd August, and we found that the reception committee had numerous representatives on the railway platform, distinguished by badges of blue ribbon, to receive foreign members, and advise them as to lodgings, \&c. From what we observed on several occasions during succeeding visits to the Central Station of Berlin, the labours of these gentlemen were of a most arduous nature, extending from early morning till late at night. Our first duty on Saturday forenoon was to proceed to the old Prussian Parliament House, 75 Leipzigerstrasse, to obtain membership tickets and badges, and various guides and tickets of admission to the social entertainmentsincluding that for the never-to-be-forgotten Municipal Banquet in the Town Hall, on Tuesday, the 5th August. The sectional meetings of the Congress and the Medical Exhibition were held in the Ausstellungs-Park, Alt Moabit, and as the Medical Exhibition was opened on Saturday, the 2nd August, we spent the most of the day inspecting the exhibits. The Ausstellungs-Park contains a large picture gallery, in the different halls of which the sections met, besides numerous restaurants, panoramas, theatres, and other places of entertainment. It is difficult to give any idea of the extent and completeness of the Medical Exhibition, but owing to the want of space there seemed to us to be some irregularity in the grouping of different exhibits. Among the objects of interest we would call special attention to the splendid display of field ambulance apparatus shown by the authorities of the German War Office. This exhibit included field hospitals, which were transportable and capable of being erected in a very short time; all kinds of vehicles for carrying wounded by road or rail; cooking apparatus; and travelling disinfecting machines. One gentleman, who explained the different parts of the ambulance exhibit to us, made the commonplace remark that there was no greater security of peace than perfect preparation for war. It struck us that the preparations 
for war, as seen not only in the Exhibition but all over Berlin itself, were of the most perfect kind, but we were not quite so sure that the certainty of peace wias a necessary or even a probable consequence. These immense armaments, we think, cannot exist without in themselves constituting one direct incentive to warfare, by provoking the desire to give the armies something real to do. Another series of exhibits worthy of mention was the collection of frozen sections of the body, illustrating the different stages of pregnancy and the puerperal state; and the forensic medicine casts and models were of the most ghastly and realistic description. One section of the Exhibition was devoted to illustrating the medical periodical publications of the world, and among the journals we noticed the last half-yearly volume of the Glasgow Medical Journal. There was, of course, the usual display of surgical and scientific instruments, and of every variety of foods and drugs, samples of the latter being scattered broadcast among the members.

The opening ceremony of the Congress was held in the Circus Renz, Karlstrasse, on Monday forenoon, 4th August, at 11 o'clock. A gaily decorated triumphal arch had been erected before the entrance to the circus, and the street was lined with mounted police. Long before 11 o'clock the vast circular building was filled, and every available inch of sitting and standing space was occupied when the proceedings commenced. The circus was illuminated with electric light, the rays of the sun having been carefully excluded, and the circular arrangement of the seats gave the spectator an idea of the enormous size of the gathering, which he could not otherwise have obtained. From a rough estimate we calculated that about 6,000 persons, including many ladies, were present; but, from accounts since published, we learn that the first meeting was composed of not less than 7,000 persons. The platform and speaker's desk were erected at the base of an enormous statue of Asculapius, by Westphal, which gleamed of a pearly white in the rays of electric light which had been brought to bear upon it. To the right of the platform, and to the left of the main entrance to the circus, was situated the Royal box, in which had been placed a bust of the Kaiser, also illunined by electric light. The central ring of the circus had been reserved for the official delegates to the Congress, and for the members of the Corps Diplomatique, and from the ring a wide staircase led up to the feet of Esculapius, where the dignitaries of the Congress sat. It is difficult to imagine a more gay and animated scene than this great meeting presented. The 
gorgeous uniforms of military men scattered here and there, the gay summer costumes of the ladies occupying the boxes, and the numerous crosses and stars which adorned the breasts of many a savant gave a pleasant relief to the dark and sombre habiliments of the ordinary civilian members. Shortly after 11 o'clock Virchow ascended the reading desk, and delivered his address of welcome. His breast was covered with decorations; and his voice, though strong at first, soon became feebler, although the articulation remained clear to the end. He was followed by Dr. Lassar, secretary of the Congress, who spoke in a strong, loud, and clear voice. He stated that 2,500 German and an equal number of foreign members had already joined, and that over 1,000 ladies accompanied the members. The numbers were still increasing, and he expected that there would at the last be more than 6,000 members. Virchow is a slightly built but active old man of medium height; his hair and beard are grey; his complexion is a light yellow; and his expression is genial and smiling-altogether a lovable old man, and greatly revered by his fellow-countrymen, although many of his colleagues, as we learned in conversation with a distinguished neurologist, consider that his political proclivities have greatly interfered with his splendid scientific work. Dr. Lassar is a short, burly man, with a round, bullet head, and closely cropped hair, having all the physical strength, as well as the intellectual vigour, necessary for successfully carrying through this great undertaking. After Lassar's address complimentary speeches were delivered by representatives of the Government, Municipality, and the Berlin practitioners; and one of the most interesting parts of the entire ceremony was the delivery of short addresses by the National Deputies. The most loudly applauded deputy, who received indeed a perfect ovation, was Sir James Paget, and following close upon him came Bacelli, the Italian representative. He delivered an address in Latin, which, though not understood by the majority, was thoroughly enjoyed as a piece of oratory, and there can be no doubt that Bacelli was the orator of the Berlin Congress. In a German daily paper we noticed that Bacelli, who is a statesman as well as a man of science, so far back as 1869 had been called by the great Broussais the "Demosthenes and Cicero of modern science," a compliment of which he proved himself well worthy on the 4th August last. After the addresses of the delegates the proceedings dragged a little, and between 1 and 2 o'clock the majority of the members went out for refreshment and sunlight, and barely a third of the vast assemblage remained to hear the addresses of 
Lister and Koch. We thought that the earlier parts of the programme might have been curtailed a little, and particularly that the latter part of Virchow's address was unnecessarily drawn out. We felt that our distinguished fellow-countryman, who began his investigations on antiseptic surgery in our own Royal Infirmary, scarcely got a fair chance. But some little drawbacks of this kind were perhaps unavoidable in arranging for such a monster meeting of all nationalities.

The second and third general meetings were held on Wednesday the 6th and Saturday the 9th August in the same place, and they require no further mention here.

The work of the Sections, of which, including 2 sub-sections, there were 20 in all, began in the Art Galleries of the Ausstellungs-Park on Monday afternoon, and during the remaining days of the Congress they were kept very busy, some 700 communications having to be received in all. We attached ourselves to the Section of Pathology, and by so doing we became acquainted with the method of procedure in all. The first duty was to elect the officebearers, a purely formal function, and then the members of the section in turn inscribed their names in the official list. When this had been done the secretaries took their places, and the work of the pathologists, according to the daily programme, commenced. At the meetings of this section we had the pleasure of seeing and being introduced to many of the leaders in pathological science, including Virchow, von Recklinghausen, Zenker, Ziegler, Salomonsen of Copenhagen, Grawitz, Max Wolff, Israel, Weigert, Sims Woodhead, Welsh of Baltimore, Ponfick, and many others. In addition to numerous papers the following subjects were fully discussed:-(1) The part played by leucocytes in the formation of new tissue, introduced by Ziegler; (2) The lesions of the niyocardium, introduced by von Recklinghausen; and (3) Tuberculosis, introduced by Ponfick. The meetings were well attended throughout, and great interest was shown in many of the subjects discussed.

On Thursday, the 7th August, our distinguished townsman Dr. William Macewen took the chair in the sub-section of Orthopædic Surgery, and read an address on Osteotomy, with special reference to the employment of this operation as a means of increasing the antero-posterior pelvic diameter in difficult labour, and so avoiding the necessity for craniotomy or the Cæsarean section. We were pleased to observe that a full representation of Scotch and English members were present in this section on that day to hear Macewen, notwithstanding the fact that, owing to the section having to meet in 
an out-of-the-way corner, some difficulty was experienced by many in finding its precise location.

We were only able to attend the other sections in a somewhat cursory manner, and in all of them were to be seen men whose names are household words in medical science,

The social entertainments of the Congress were certainly not the least enjoyable features of the meeting, and, although we had not the honour of being among the favoured few invited to Court, we experienced in full measure the generous and sumptuous hospitality of the city of Berlin. On Monday evening, the 4th August, the members and their lady friends were invited to a conversazione in the Ausstellungs-Park. Abundant refreshments were provided in the Picture Galleries, and after these had been thoroughly enjoyed, in a fashion that somewhat astonished the staid Scotchmen of the gathering, the crowd wandered about the grounds enjoying the music of the military bands, rendered in a way that is only possible in the Fatherland. The artistically designed programme inforned us that the Panorama and other places of amusement in the Park were free to the guests for the evening, and that in the large dining hall of the gardens a concert and dance would be held. On arriving at the latter place a merry and enlivening scene burst upon our view. Slim fräuleins and portly fraus, grey-haired men and beardless boys, mingled together in the mazy dance, and the whole thing brought at once to our minds the mirth and jollity of the proverbial "soiree, concert, and ball" of our native city. We got back to our hotel, well pleased with the entertainment of the evening.

Beyond all doubt, however, the most memorable social entertainment of the Congress was the banquet given by the Magistrates and Town Council of Berlin. This took place on the evening of Tuesday, the 5th August, in the Municipal Buildings. From 8 to 9 o'clock in the evening the members were received at the head of the grand staircase of the Rathhaus by the Lord Provost and Magistrates, distinguished by their golden chains and medals of office. We secured seats in the large hall, distinguished by the beauty of its architecture and by the celebrated painting, which adorns its walls, of a sitting of the Berlin Diplomatic Congress, famous in England for its "peace with honour." At one of the tables in this hall sat the leaders of the Congress, with the Oberbürgermeister presiding; but owing to the conviviality which soon prevailed we could take little note of anything that occurred at this place of honour, except the chairing of Virchow and his sub-

No. 3 ,

Vol. XXXIV. 
sequent progress through the hall, which took place at a late period of the evening and under circumstances which made us tremble a little for the safety of the illustrious president of the Congress. That he sustained no harm, however, was abundantly evident early next morning, when he turned up smiling in the Ausstellungs-Park. When a sumptuous supper had been enjoyed, the guests proceeded to test the virtues of the German wines, and the effect soon became very obvious. No one kept his seat, and all began to speak at once, so that we were reminded strongly of the Tower of Babel. The air of the Banquet Hall was soon rendered misty by the smoke of the cigars, which the members extracted from the bowels of a pasteboard effigy of the Rampant Bear that figures in the Berlin coat of arms. The greatest good humour prevailed, and the leaders of medicine, as they passed up and down the hall, were enthusiastically cheered and vigorously shaken by the hand. The gathering gave anple proof of the good fellowship and brotherhood which prevails among the members of the medical profession the world over, and constitutes an episode in the lives of those who took part in it never to be forgotten.

The Congress Ball was held in the large Winter Garden of the Central Hotel, on the evening of Thursday the 7th. Owing to the great number of guests, balls had to be arranged for the overflow in other places, and on that evening there were gatherings of a similar kind in the Kaiserhof, the Zoological Gardens, and the Philharmonie, a concert hall in the west end of Berlin. The chief interest centred around the function celebrated in the Central Hotel, and certainly it afforded a very pretty sight. Two large towers of ice at either end of the hall kept the air cool; Hlowers were showered down on the company from the roof; and the floor was kept clear for the dancers by a guard of halberdiers, in the gay livery of green and red of a bygone age.

Various excursions and visits to different hospitals and sanitary institutions had been arranged for, but of these we were only able to avail ourselves of two. We visited the new hospital in the urban district of Berlin, and the Central Viehof, or cattle market, situated in the extreme north-east outskirts of the city. We were shown over the Urban Hospital by the surgical director, Dr. W. Körte, and it is difficult to imagine a more coniplete equipment for battling with disease in any hospital. The institution was opened in 1890 with about 500 beds for adults and 90 for children. The department for internal diseases is under the charge of Prof. Dr. A. Fränkel, 
that for surgery under Dr.W. Körte, each having four assistants. There are also two apothecaries, and there is a large staff of nurses and servants. The administration is under a chief inspector, and the hospital is subject to a municipal board of directors. The operating theatre is constructed on the most modern principles, the possibilities of dust accumulation in any part being reduced to a minimum. Operation tables and instrument cabinets are constructed of japanned or galvanised metal frameworks, thus avoiding all awkward corners that are likely to be overlooked in the process of cleaning. A thoroughly equipped electrical table can be brought right up to the operator and used whenever he thinks it necessary. The whole hospital is lighted with the electric light, and heated by hot air or steam. The fresh air entering the wards by the ventilating apparatus is passed through a warm chamber which heats it to $+20^{\circ} \mathrm{C}$. if necessary. A most complete system of baths is also provided in a special building, and the pathological department, though striking us as small for so large an hospital, was in keeping with the other parts of the building. The hospital is built on the pavilion system.

What chiefly interested us in our visit to the cattle market and slaughter houses, in addition to the enormous extent and sanitary cleanliness of the place, was the excellent arrangements which are in force for the macroscopic and microscopic examination of the carcasses. In the course of a long conversation with one of the assistant veterinary surgeons we gained some idea of the minuteness and care with which the inspection is carried out. The most careful microscopic examination is of course carried out with regard to the carcasses of swine. A large number of trained officials make sections of various parts of the carcass and these are put out on a long glass slide in a regular order-12 sections from each animal, and the slide capable of holding 24 sections. When the preparations have been mounted, the sections are microscopically examined seriatim. If anything the least suspicious is seen, the specimen must be sent down to the chief inspector of the department who says what is to be done. Thus, while we were in the office a suspicious slide had come down from upstairs, and in one of the specimens a structure very like the calcified capsule of a trichina spiralis was present, and was the reason of the specimen being sent for the inspector's opinion. In this case orders were given to examine another series of 12 specimens. In the case of swine, tuberculosis was the most common affection, and on some of their large slaughter days there might be found from 40 to 50 tubercular animals. The rule 
is that if the disease is definitely local and not in the very advanced stages, the healthy portions of the carcass are passed; thus we saw the register for one day on which 52 tubercular carcasses had been found, and of these 40 went free as being local, and 12 were condemned, as unfit for food. A careful note is kept of every morbid appearance discovered. Trichinosis is not very frequently met with-perhaps two or three cases in the month. In the case of cattle and sheep, the examination is, of course, mainly macroscopic, and is supervised, by two chief veterinary surgeons. Every carcass that has passed the veterinary inspection receives an official stamp, without which it cannot be sold. We most cordially commend the system to the careful consideration of our market authorities in Glasgow, as it is only of very recent date that we have been rendered alive to the urgent necessity that exists for some efficient and reliable inspection of our butcher-meat supply.

We have thus endeavoured to give our readers a general idea of what the Tenth International Congress was like, to an ordinary private member. There can be no doubt that the Berlin Congress was, everything taken into consideration, the greatest of all the International Congresses, although in certain points it may have been surpassed by previous gatherings. Thus, one gentleman who was attending his fourth International Congress informed us that for homely, social enjoyment and generous hospitality on the part of the Royal House and the citizens, the Congress of Copenhagen surpassed any that he had had experience of. In our own experience the London Congress of 1881 was superior to the Berlin one in its organisation, and in the accommodation that that was provided in Burlington House for the sittings of the sections. It was a great matter to have the sections meeting in separate apartments; in Berlin the constant passing backwards and forwards of members constituted a continuous source of distraction. A member thought nothing of entering a section or leaving it, when he had no door to go through, whereas, if there had been a door, he would probably have thought twice before going in, or have sat for a reasonable time if he did. With regard to the general meetings of the Congress, St. James' Hall in London could not in the least bear comparison with the splendour of the Circus Renz. We cannot, of course, venture to express any opinion with regard to the scientific value of the work of the Congress, as this can only be done when the Transactions have appeared.

J. L. S. 